\title{
Struggle for Democracy in Sub-Saharan Africa
}

\author{
Tatu Vanhanen \\ Department of Political Science, University of Helsinki, Suopolku 4D, 01800 Klaukkala, Finland. \\ E-mail: tatu4@saunalahti.fi
}

This article seeks explanation for the success and failures of the process of democratization in sub-Saharan Africa. Point of departure is the idea that the distribution of power resources is crucial in this respect. The comparative analysis confirms this idea, both on the global level as for the sub-Saharan countries. The cross-national variation within Africa is discussed on the case-level, which allows to take other explanations like violence and ethnicity into account.

Acta Politica (2004) 39, 207-247. doi:10.1057/palgrave.ap.5500066

Keywords: democratization; sub-Saharan Africa; measures of democracy; explanation of democratization; statistical analysis

\section{Introduction}

Most of the 45 sub-Saharan African countries are not yet democracies, but it is remarkable that there is striving for democracy in practically all of them and that some countries have successfully crossed the threshold of democracy. ${ }^{1}$ The purpose of this paper is to seek explanation for the successes and failures of democracy in sub-Saharan Africa. ${ }^{2}$ How to explain the considerable variation in the level of democratization among African countries? Is there any common explanation? My central argument is that the evolutionary resource distribution theory of democratization used in my global studies provides a satisfactory explanation for the level of democratization in sub-Saharan Africa, too.

Various theoretical explanations for democracy and democratization have been presented in research literature (see, for example, Dahl, 1971, 1989, 1998; Diamond et al., 1990; Arat, 1991; Hadenius, 1992; Rueschemeyer et al., 1992; Midlarsky, 1997; Diamond, 1999; Berg-Schlosser and Mitchell, 2000; Przeworski et al., 2000). I discuss these and some other theoretical explanations in my book (Vanhanen, 2003), which covers 170 contemporary countries. The space does not allow to review them in this connection. The problems of democracy in sub-Saharan Africa have been explored from different perspectives in many excellent recent studies (see, for example, Glickman, 1995c; Clark and Gardinier, 1997; Decalo, 1998; Chazan et al., 1999; Idehuru, 1999; Mbaku et al., 2001). I will refer to some of them in connection to single African countries. 


\section{An Evolutionary Resource Distribution Theory of Democratization}

I have derived a causal explanation for democratization from a Darwinian interpretation of politics (see Vanhanen, 1997, 21-26; 2003, 25-31). Briefly stated, it is argued that the political struggle for power and scarce resources constitutes a forum of the general struggle for existence, which is explained by the Darwinian theory of evolution by natural selection. The struggle for existence is inevitable and omnipresent in nature (see, for example, Dobzhansky et al., 1977, 86-99; Alexander, 1980, 15-22; Mayr, 1982, 479$480 ; 1988,215-232)$. So is the political struggle for power and scarce resources in human societies. Because power is based on sanctions, the distribution of power must depend on the distribution of sanctions. When important intellectual, economic and other resources used as sanctions are distributed widely among people and various groups, circumstances are conducive to the distribution of power and, consequently, to democratization. When important power resources are concentrated in the hands of the few, no matter what type of group it is, circumstances are conducive to the concentration of political power in the hands of the few and to an autocratic political system.

On the basis of this argumentation, it is hypothesized that democratization takes place under conditions in which power resources have become so widely distributed that no group is any longer able to suppress its competitors or to maintain its hegemony. According to this theory, democratization in some form is a more or less inevitable consequence of resource distribution. This regularity is assumed to apply to all populations and nations across cultural, geographical, civilizational, racial, and other boundaries because all human populations share the same evolved behavioral dispositions. The theory can be tested by empirical evidence by developing empirical variables to substitute the hypothetical concepts of 'democratization' and 'resource distribution.'

\section{Measures of Democracy}

My measures of democracy take into account two crucial dimensions of democratization: the degree of competition and the degree of participation. The Competition variable indicates the percentage share of the smaller parties (100 minus the share of the largest party) of the votes or of the seats in parliamentary and/or executive elections. The Participation variable indicates the percentage of the total population who voted in the same election(s), but this variable has been complemented by taking into account the impact of referendums on democracy. Referendums are taken into account for the reason that the number and significance of referendums is increasing in many countries, although their significance in sub-Saharan Africa is still small. Referendums can be regarded as the most common and important form of 
direct democracy in the contemporary world. These measures of democracy are described in greater detail and data on them are documented in book (Vanhanen, 2003; see also Vanhanen, 2000).

The impact of referendums is added to the Participation variable in such a way that each national referendum increases Participation by five percentage points and each state/provincial referendum by one percentage point for the year when the referendum was held. The upper limit for the contribution of referendums is 30 percentage points for a year. It means that not more than six national or 30 state/provincial referendums are taken into account in a year. Besides, the upper limit for Participation variable is 70 . The same upper limit is applied to the Competition variable. These cutoffs in the two basic variables are intended to reduce the effect of extreme cases and also the effect of differences in electoral and party systems on the values of these measures of democracy. The $30 \%$ upper limit for the impact of referendums is arbitrarily selected. It is intended to leave more room $(40 \%)$ for the impact of electoral participation.

The two basic measures of democracy are combined into an Index of Democratization (ID) by multiplying Competition and Participation and by dividing the outcome by 100 . Because of multiplication, ID gets high values only if the values of both basic variables are high. For example, if Participation is $60 \%$ and Competition zero, ID value would also be zero.

Both basic variables are continuous, but it is possible to use them to separate democracies from nondemocracies by defining threshold values of democracy. In the global study, $30 \%$ for Competition and $20 \%$ for Participation are used as threshold values. The same threshold values will be used in this paper to separate democracies from non-democracies. The countries slightly below or slightly above these minimum thresholds of democracy could be regarded as semidemocracies, but this intervening category is not used in this study. ${ }^{3}$

\section{Explanatory Variables}

Five empirical variables are used to measure resource distribution from different perspectives. Per capita income has been used in many other studies to measure the level of economic development and wealth. In this study it is used as an indicator of resource distribution. It is assumed that economic resources are usually the more widely distributed, the higher per capita income is. Real GDP per capita (PPP\$) in 1998 is used as the principal indicator of per capita income. For the purposes of statistical analysis, data on this variable were transformed into percentages (GDP\%) by taking 25,000 dollars per capita to represent the level of $100 \%$. Percentages are calculated from 25,000 dollars per capita. The upper limit for this variable is $100 \%$, although a country's real 
GDP per capita were higher than 25,000 dollars. Most data on real GDP per capita (PPP\$) in 1998 are from UNDP's (the United Nations Development Programme) Human Development Report 2000.

The Students and Literates variables are used as indicators of intellectual power resources. The Students variable indicates the number of students in universities per 100,000 inhabitants. The absolute numbers per 100,000 inhabitants were transformed into percentages by calculating percentages from 4,000 students per 100,000 inhabitants. As in the case of GDP $\%, 100 \%$ is the upper limit for this variable. The Literates variable concerns the rate of adult literacy. Most data on Literates are from UNDP's Human Development Report 2000, and most data on Students from UNESCO'S (1999) Statistical Yearbook 1999.

The Family Farms (FF) variable is intended to measure the percentage of family farms of the total area of holdings. Data on this variable are from many sources over the period 1960-1998, especially from the results of agricultural censuses. The latest data are from FAO's (1997) Report on the 1990 World Census of Agriculture. Because of their community-based land tenure systems, it has been difficult to estimate the share of family farms in the countries of sub-Saharan Africa. In this study, I decided to include $50 \%$ of the land under de facto community-based land tenure systems into the category of family farms. As a consequence, the estimated shares of family farms vary from 30 to $45 \%$ in most African countries. Data on African land tenure systems are principally from John W. Bruce's (1998) book Country Profiles of Land Tenure: Africa 1996.

The values of the DD variable (the degree of decentralization of mainly nonagricultural economic power resources) are estimations, but certain criterion variables were used to constrain and guide estimations. As the starting point is the assumption that extreme poverty as well as the concentration of economic resources in the hands of a small minority constrain the decentralization of economic power resources and thus provide objective grounds to limit the scope of estimations. It is plausible to argue that people below the poverty line are without any effective economic resources to participate in national politics, or even in local politics. Therefore, statistical data on the percentage of people below the poverty line are used to constrain the value of DD in such a way that the value of DD should not be higher than 100 minus the percentage of people below the poverty line. Statistical data on the population below the poverty line are principally taken from the World Bank's $(2000,2001)$ World Development Report and from UNDP's $(2000,2001)$ Human Development Report. If more than one percentage is given for a country in these sources, the arithmetic mean of percentages was calculated. These sources give data on poverty for more than 100 countries. Data were complemented from other sources, and for countries from which no data are 
available, the value of the Poverty Line variable was estimated on the basis of data concerning neighboring countries or other countries in similar conditions.

Data on the highest $10 \%$ share of income or consumption are used to indicate the relative differences in the concentration of economic power resources. My argument is that economic power resources are much more concentrated in a country in which the highest $10 \%$ share of income or consumption is high than in a country in which it is low. Therefore it is reasonable to use the Highest $10 \%$ variable to constrain the value of DD in such a way that it should not be higher than 100 minus the percentage of the Highest $10 \%$ minus 10. Empirical data on Highest $10 \%$ were gathered from the World Bank's (2000, 2001) World Development Report and from UNDP's (2000, 2001) Human Development Report. If there are more than one percentage for a country, the mean of percentages was calculated. For the countries from which no data are available, the value of Highest $10 \%$ was estimated on the basis of neigboring countries or other comparable countries.

In addition to Poverty Line and Highest $10 \%$ variables, economic freedom ratings published in Economic Freedom of the World: 2000 Annual Report (Gwartney and Lawson (with Samida), 2000) are used to constrain the values of DD. The economic freedom ratings calculated in that book are intended to evaluate the nature of economic systems from the perspective of economic freedom. The ratings vary from 0 to 10 in such a way that the higher the rating value, the higher the level of economic freedom. It is reasonable to assume that, to some extent, these ratings measure the distribution of economic power resources, too. For the purposes of this study, these ratings were multiplied by 10. The multiplied ratings are used to guide the estimations of DD values in such a way that a DD value should not be more than 20 scores lower or 20 scores higher than the multiplied economic freedom rating for the country. However, the criteria of economic freedom used by Gwartney and Lawson are not intended to measure the distribution of economic power resources. Therefore, it has been necessary to deviate from the criteria defined above especially in the cases in which economic power resources are highly concentrated. Furthermore, scores of economic liberalization given in Nations in transit 2001 (Karatnycky et al., 2001) are used to constrain the estimations of DD in former socialist countries.

In most cases, the values of DD are calculated by subtracting from 100 the sum of percentages of Poverty Line and Highest $10 \%$ variables. The value of DD is usually rounded downward to the nearest ten, except in the cases in which the sum of Poverty Line and Highest $10 \%$ variables rises to near 100 or over 100. In some cases, economic freedom ratings or scores of economic liberalization have determined the values of DD. Other information about economic systems has been taken into account especially in the cases in which 
economic power resources are extremely concentrated. Because of the use of several criterion variables, the new DD variable is principally based on empirical data, and the scope of subjective judgments is in most cases quite limited. It is assumed that the higher the value of $\mathrm{DD}$, the more widely the ownership and control of nonagricultural economic power resources are decentralized in a country and the better the social conditions are for democracy.

The five basic explanatory variables can be used separately to explain democratization, but I think that a combination of them would be a theoretically more valid substitute for the hypothetical concept of "resource distribution' than any of them separately. All of the five basic explanatory variables are intended to measure some aspects of resource distribution, which is the theoretical explanatory factor. The problem is how to combine the five explanatory variables. Because Students and Literates are intended to measure the distribution of intellectual power resources from the perspective of education, they are combined into a sectional Index of Intellectual Power Resources (IR) by calculating the mean of the two percentages. FF and DD have been combined into a sectional Index of Economic Power Resources (ER) by a formula: $\mathrm{ER}=(\mathrm{FF} \times \mathrm{AP})+(\mathrm{DD} \times \mathrm{NAP})$. In other words, the values of FF and DD are weighted by percentages of agricultural (AP) and nonagricultural populations (NAP) respectively because the percentage of agricultural population varies greatly in the world.

There would be many ways to combine the explanatory variables. Three different combinations are used because it is difficult to know which would be the most justified method to combine explanatory variables. The Index of Power Resources (IPR), which is calculated by multiplying the values of the two sectional indices IR and ER and by dividing the outcome by 100, will be used as the first combination. This index $(\mathrm{IPR}=(\mathrm{IR} \times \mathrm{ER}) / 100)$ is based on only four basic explanatory variables (Students, Literates, FF, and DD), which are combined into two sectional indices, and it produces high values if the values of both indices are high. The Extended Index of Power Resources (IPR-2), which is calculated by multiplying the values of GDP\%, IR, and ER and by dividing the outcome by 10,000 , is the second combination of explanatory variables: IPR- $2=(\mathrm{GDP} \% \times \mathrm{IR} \times \mathrm{ER}) / 10,000$. Because of multiplication, it produces high values only if all components have high values. Any low value of a component will decrease the value of IPR drastically. Finally, the arithmetic mean of the five single explanatory variables (Mean) will be used as the third combination. The Mean variable differs from the two indices of power resources in one important respect. A low value of any single variable will not decrease the value of this combination drastically. In other words, high values of some variables can compensate low values of some other basic variables. 


\section{Research Design}

The operational definition of the measures of democratization and of resource distribution makes it possible to reformulate the original hypothesis about democratization into two research hypotheses:

(1) The measures of democracy are positively correlated with the measures of resource distribution, especially with the combined indices of power resources.

(2) All countries tend to cross the threshold of democracy at about the same level of resource distribution.

Because all data on empirical variables are at the level of interval measurement, hypotheses can be tested by correlation and regression techniques. Correlations test the first hypothesis. Positive correlations should be relatively strong. Weak or negative correlations would falsify the hypothesis, which presupposes a strong positive correlation between the measures of democratization and the explanatory variables. The stronger the correlations are, the more confidently we can assume that the distribution of power resources is causally related to the variation of democratization.

The second hypothesis can be tested by regression analysis. If the results of regression analysis show that countries have not tended to cross the threshold of democracy at about the same level of IPR and other indices of resource distribution, the second hypothesis should be regarded as falsified. Deviating cases weaken the hypothesis, but if the number of deviations remains relatively small, they are not enough to falsify the hypothesis. It should be noted that because the operational indicators used in this study are not perfect substitutes for hypothetical concepts and because there are other factors affecting democratization, it would be unrealistic to expect complete relationship between dependent and independent variables. We have to accept some variation around the average transition level.

The problem is how to define the transition level of resource distribution. If ID (the index of democratization) and the three indices of power resources were exactly in the same scale, it would be reasonable to hypothesize that countries tend to cross the threshold of democracy as soon as the value of IPR, IPR-2, or Mean rises to the level of 10 index points, because countries have usually crossed all threshold values of democracy when ID is at the level of 6-10 index points. However, the scales of explanatory indices are not the same as the scale of ID. Therefore, it is necessary to define the transition level of resource distribution separately for each index of power resources. The value of an explanatory index at which the regression line crosses the ID value of 10 index points provides the basis to define the transition level of resource distribution. When the transition level is defined, it is reasonable to hypothesize that all countries above the upper limit of the transition level 
tend to be democracies and all countries below the lower limit of the transition level tend to be non-democracies.

\section{Hypotheses tested in the total group of 170 countries}

Let us first explore the intercorrelations of the five explanatory variables and their combinations in the total world group of 170 countries (Table 1).

All intercorrelations are positive, but the strength of correlations varies greatly. Students, Literates, GDP\%, and DD are moderately or strongly intercorrelated, whereas FF is weakly correlated with Students and Literates. The fact that the five basic explanatory variables are in most cases only moderately intercorrelated implies that they indicate different aspects of the fundamental explanatory factor (resource distribution) and that, therefore, their combinations may measure the variation in resource distribution more validly than any of them alone. The two sectional indices, IR and ER, are relatively weakly correlated with each other $(0.414)$, which implies that they represent to some extent different dimensions of resource distribution.

The three combined indices (IPR, IPR-2, and Mean) are strongly intercorrelated (from 0.906 to 0.954 ), which shows that the three different methods to combine the basic explanatory variables have produced highly similar results. Their correlations with the five basic explanatory variables are moderate or strong (from 0.485 to 0.950 ). All of them are most strongly correlated with DD, and the weakest correlations are with Literates and FF. IPR and IPR-2 are clearly more highly correlated with ER than with IR, whereas Mean is correlated more strongly with IR than with ER.

Table 1 Intercorrelations of the five explanatory variables and their combinations in the total world group of 170 countries

\begin{tabular}{lccccccccc}
\hline Variable & Students & Literates & $F F$ & DD & IR & ER & IPR & IPR-2 & Mean \\
\hline GDP\% & \multirow{2}{*}{0.676} & 0.548 & 0.507 & 0.739 & 0.664 & 0.619 & 0.792 & 0.902 & 0.891 \\
Students & & 0.708 & 0.304 & 0.688 & 0.928 & 0.498 & 0.805 & 0.701 & 0.848 \\
Literates & & & 0.120 & 0.526 & 0.920 & 0.262 & 0.620 & 0.485 & 0.727 \\
Family Farms & & & & 0.612 & 0.232 & 0.782 & 0.658 & 0.629 & 0.626 \\
DD & & & & & 0.659 & 0.909 & 0.950 & 0.861 & 0.886 \\
IR & & & & & & 0.414 & 0.773 & 0.645 & 0.854 \\
ER & & & & & & 0.882 & 0.805 & 0.758 \\
IPR & & & & & & & 0.914 & 0.954 \\
IPR-2 & & & & & & & & & 0.906 \\
Mean & & & & & & & & & \\
\hline
\end{tabular}

$\mathrm{DD}=$ degree of decentralization; IR = intellectual power resources; $\mathrm{ER}=$ economic power resources; IPR = index of power resources; IPR-2 = extended index of IPR. 
Table 2 Correlations between the 10 explanatory variables and the three measures of democracy in 2001 in the total world group of 170 countries

\begin{tabular}{lccc}
\hline Explanatory variable & $\begin{array}{c}\text { Competition } \\
2001\end{array}$ & $\begin{array}{c}\text { Participation } \\
2001\end{array}$ & $\begin{array}{c}\text { ID } \\
2001\end{array}$ \\
\hline GDP\% (Real GDP per capita (PPP) in 1998 & 0.425 & 0.453 & 0.620 \\
Students & 0.570 & 0.619 & 0.734 \\
Literates & 0.467 & 0.555 & 0.585 \\
Family Farms & 0.385 & 0.311 & 0.481 \\
DD & 0.699 & 0.652 & 0.839 \\
IR (index of intellectual power resources) & 0.562 & 0.636 & 0.715 \\
ER (index of economic power resources) & 0.615 & 0.545 & 0.734 \\
IPR (index of power resources) & 0.675 & 0.677 & 0.848 \\
IPR-2 (extended index of power resources) & 0.522 & 0.570 & 0.729 \\
Mean (of five basic explanatory variables) & 0.625 & 0.640 & 0.808 \\
\hline
\end{tabular}

Data on political variables are from the years 1999-2001, but because data on different years are extremely highly intercorrelated, it is enough to take into account only the latest year 2001 in this connection. The correlation between Competition and Participation for 2001 is 0.662 . Because their covariation is not more than $44 \%$, they seem to measure clearly different dimensions of democratization. Consequently, their combination, the ID, may be a more valid measure of democracy than either of the basic variables alone.

The first hypothesis can now be tested by correlating the three measures of democracy in 2001 with the measures of resource distribution (Table 2).

All the correlations given in Table 2 are clearly positive as hypothesized. Thus the results of correlation analysis support the first research hypothesis strongly. It is remarkable that Competition and Participation are approximately as strongly correlated with explanatory variables, which supports the assumption about their equal importance as measures of democracy. All correlations between ID and explanatory variables are higher than corresponding correlations between the two basic political variables and explanatory variables. This clear difference implies that the Index of Democratization is a better measure of democratization than either of the two basic variables separately.

The five single explanatory variables are intended to measure the relative degree of resource distribution from partly different perspectives. Correlations indicate how much each of them is able to explain separately, but because all explanatory variables are to a significant extent overlapping, their explanatory powers are also overlapping. I am not primarily interested in their separate explanatory powers because all of them are assumed to measure the same fundamental explanatory factor, the distribution of power resources. 
Table 2 shows that GDP\% is not particularly strongly correlated with the measures of democracy. The explained part of variation rises to $38 \%$ in the case of ID-2001. This is a significant degree of explanation, but I do not regard per capita income as the dominant explanatory variable. Of the five single explanatory variables of this study, only FF explains less of the variation in ID than GDP\%. The point is that the level of economic development as measured by per capita income furthers democratization to the extent that it indicates the distribution of socioeconomic power resources. Usually, the higher per capita income is, the more widely economic power resources are distributed, but there are many exceptions to this rule.

The students variable is moderately correlated with Competition and Participation and strongly with ID. The correlations between Literates and political variables are clearly weaker. This may be a consequence of the fact that the adult rate of literacy is $90 \%$ or higher in 78 countries. The literates variable is still an important explanatory variable. It is easier to maintain autocratic political systems in countries in which the number of literate and educated people is low than in countries where it is high. Students and Literates represent the two extreme ends of the spectrum of education. Their average, the Index of Intellectual Power Resources (IR), is assumed to measure the relative distribution of intellectual power resources better than either of the basic variables separately. The correlations of political variables with IR are moderate but weaker than with Students. The explained part of variation rises to $51 \%$ in the case of ID-2001. This finding supports the assumption about the significance of intellectual power resources in politics.

The correlations between FF and political variables are lower than correlations of any other explanatory variable. FF explains not more than 23 percent of the variation in ID-2001. The low performance of FF as an explanatory variable is related to the fact that the value of this variable differs significantly from the values of the other explanatory variables in many countries. One favorable social condition is not enough to cause democratization if other circumstances are unfavorable for democracy and, vice versa, one unfavorable condition may not be enough to prevent democratization if other conditions are favorable for democracy. In spite of relatively low correlations, the nature of land tenure system has not lost its political significance. When the ownership and control of economic power resources based on agricultural land is distributed widely among family farmers, the chances of democracy are better than in countries where the ownership and control of agricultural land is concentrated in the hands of the government or of the big private landowners.

DD (decentralization) is more strongly correlated with political variables than any of the other four explanatory variables. It explains $70 \%$ of the variation in ID-2001. FF and DD were combined into the ER because it is reasonable to assume that their combination reflects the overall degree of 
resource distribution better than either of them alone. ER explains $54 \%$ of the variation in ID-2001. It should be noted that IPR is based on IR and ER, not directly on DD.

Each of the explanatory variables explains a significant part of the variation in the degree of democratization, but because these variables are to a great extent overlapping, it is not justified to argue that democratization is principally explained by any single explanatory variable. It is more reasonable to use their combinations for this purpose. Table 2 shows that the three combinations (IPR, IPR-2, and Mean) are more strongly correlated with ID2001 than single explanatory variables (except DD) and IR and ER. The strongest correlation (0.848) is between IPR and ID-2001. The explained part of variation $\left(r^{2}\right)$ rises to $72 \%$, which represents an extremely high level of explanation. The results of correlation analysis support strongly the first research hypothesis about the positive relationship between the explanatory variables of this study and the measures of democracy.

The second research hypothesis presupposes that all countries tend to cross the threshold of democracy approximately at the same level of resource distribution and that, consequently, resource distribution causes democratization in all countries in which the degree of resource distribution is sufficiently high and prevents democratization in countries in which the degree of resource distribution is too low. Regression analysis is used to test this hypothesis. In this connection, the testing of the second research hypothesis is restricted to the regression of ID-2001 on IPR, because ID-2001 is more highly correlated with IPR than with the two other combinations of explanatory variables (IPR-2 and Mean). Figure 1 summarizes the results of this regression analysis. The results of this regression analysis for 45 sub-Saharan African countries are presented in Table 5 .

We can see from Figure 1 that the regression line crosses the ID level of 10 index points approximately at the level of 15 IPR index points. Consequently, it is reasonable to define the transition level of IPR from 10 to 20 . There are several non-democracies above the transition level of IPR, but they are not sub-Saharan African countries, whereas most deviating democracies below the transition level of IPR are sub-Saharan African countries: Benin, the Central African Republic, Chad, Gambia, Guinea-Bissau, Mosambique, Nigeria, and Senegal (see Table 5). It is justified to conclude that, with some exceptions, the transition level of IPR separates democracies from nondemocracies quite satisfactorily, although the number of deviating democracies is relatively large in sub-Saharan Africa. Deviating cases leave room for other explanatory factors, including cultural, historical, institutional, external, and accidental factors. Figure 1 also shows how well the average relationship (regression line) between IPR and ID-2000 explains the actual values of ID in single countries and which countries deviate most clearly from the average pattern. 


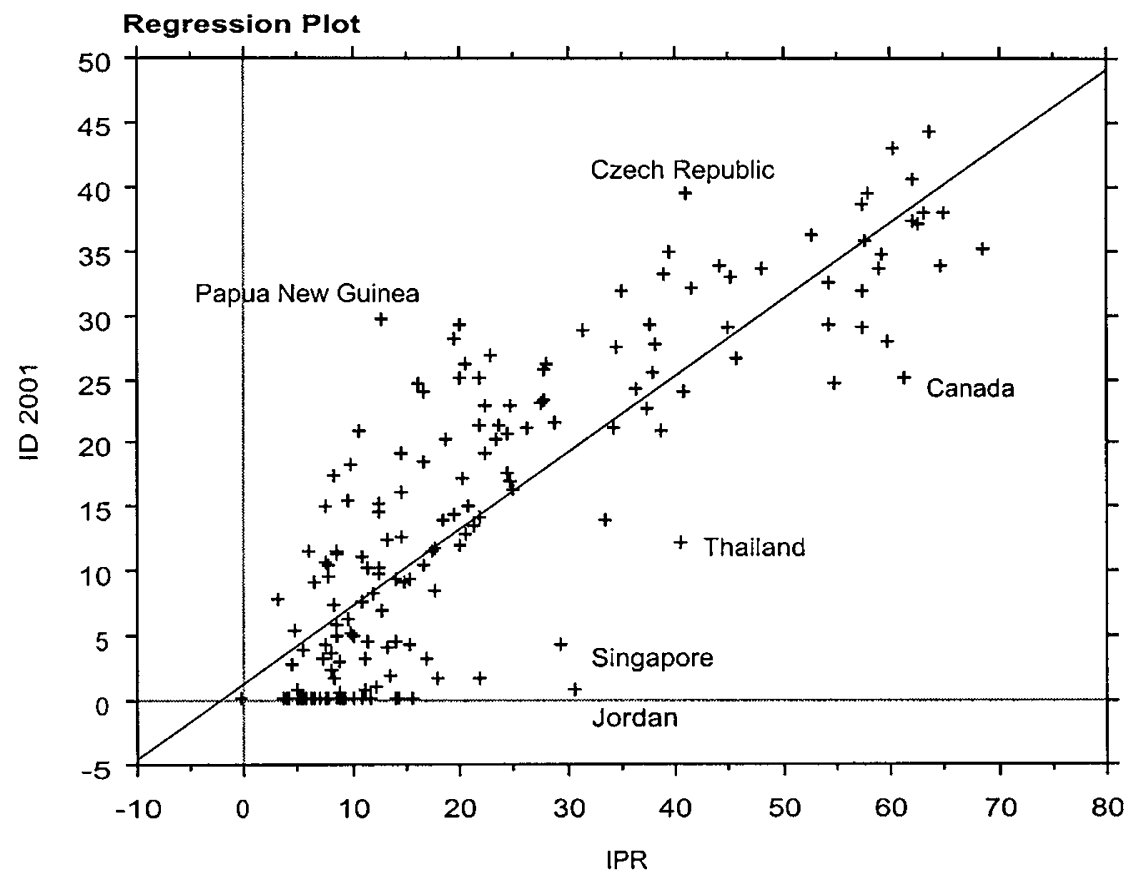

$Y=1.441+0.595 * X ; R^{2}=0.719$

Figure 1 Results of regression analysis of ID-2001 on IPR for single countries in the global group of 170 countries.

The results of the global analysis show that the level of resource distribution provides a quite satisfactory explanation for the lack of democracy and for the low level of democracy in nearly all African countries. Because the ID varies significantly among African countries, it is reasonable to ask to what extent IPR is able to explain this variation in the sub-group on 45 sub-Saharan African countries.

\section{Hypotheses tested in the sub-group of $\mathbf{4 5}$ sub-Saharan countries}

We cannot expect as strong relationship between ID and IPR in the sub-group of 45 sub-Saharan African countries as in the global group of 170 countries for the reason that the variation both in ID and in IPR is much more limited in this sub-group than in the global group. However, correlations should be positive. Let us first examine the intercorrelations of explanatory variables.

Table 3 shows that explanatory variables are more weakly intercorrelated in this sub-group of 45 countries than in the global group of 170 countries 
Table 3 Intercorrelations of the five explanatory variables and their combinations in the sub-group of 45 sub-Saharan African countries

\begin{tabular}{|c|c|c|c|c|c|c|c|c|c|}
\hline Variable & Students & Literates & $F F$ & $D D$ & $I R$ & $E R$ & $I P R$ & $I P R-2$ & Mean \\
\hline GDP $\%$ & 0.729 & 0.524 & -0.582 & 0.505 & 0.617 & -0.102 & 0.519 & 0.911 & 0.719 \\
\hline Students & & 0.457 & -0.367 & 0.402 & 0.615 & -0.138 & 0.488 & 0.697 & 0.674 \\
\hline Literates & & & -0.371 & 0.350 & 0.983 & -0.257 & 0.762 & 0.511 & 0.882 \\
\hline Family Farms & & & & -0.326 & -0.405 & 0.441 & -0.151 & -0.489 & -0.280 \\
\hline DD & & & & & 0.395 & 0.441 & 0.706 & 0.676 & 0.640 \\
\hline IR & & & & & & -0.256 & 0.778 & 0.599 & 0.923 \\
\hline ER & & & & & & & 0.378 & 0.177 & 0.034 \\
\hline IPR & & & & & & & & 0.715 & 0.893 \\
\hline IPR-2 & & & & & & & & & 0.759 \\
\hline Mean & & & & & & & & & \\
\hline
\end{tabular}

See Table 1 for explanation.

(see Table 1). Besides, FF is negatively correlated with the four other basic explanatory variables, which decreases the correlations between ER and other variables to near zero or slightly negative. FF deviates drastically from the other explanatory variables mainly for the reason that there is not much variation in the estimated shares of family farms in sub-Saharan Africa (cf. Vanhanen, 1997, Appendix 3; 2003, Appendix 3). As noted above, the estimated shares of family farms vary from 30 to $45 \%$ in most sub-Saharan African countries. According to my interpretation, the relatively strong position of family farms constitutes a favorable precondition for democratic politics in Africa, but because there is not much variation in this variable, it cannot be highly correlated with other explanatory variables. Most intercorrelations between other explanatory variables are moderate.

The correlations between explanatory variables and the measures of democracy test the first research hypothesis (Table 4).

Correlations between FF and the three measures of democracy are slightly negative, whereas the other correlations are positive as hypothesized. So the results of correlation analysis support the first research hypothesis also in this sub-group of 45 sub-Saharan African countries, but because most correlations are weak or only moderate, the support is weak. It is evident that the measures of resource distribution explain only a small part of the variation in the level of democratization within this sub-group of countries. IPR explains $18 \%$ of the variation in ID-2001, IPR-2 explains $24 \%$, and Mean not more than $10 \%$. So I come to the conclusion that resource distribution (IPR) does not provide a satisfactory explanation for the variation in ID-2001 within the sub-group of 45 sub-Saharan African countries, although it explains $72 \%$ of this variation in the global group of 170 countries. 
Table 4 Correlations between the 10 explanatory variables and the three measures of democracy in 2001 in the sub-group of 45 sub-Saharan African countries

\begin{tabular}{lccr}
\hline Explanatory variable & $\begin{array}{c}\text { Competition } \\
2001\end{array}$ & $\begin{array}{c}\text { Participation } \\
2001\end{array}$ & \multicolumn{1}{c}{ ID } \\
\hline GDP\% (Real GDP per capita (PPP) in 1998 & 0.177 & 0.344 & 0.345 \\
Students & 0.085 & 0.187 & 0.221 \\
Literates & 0.070 & 0.243 & 0.173 \\
Family Farms & -0.092 & -0.261 & -0.244 \\
DD (degree of decentralization) & 0.267 & 0.352 & 0.468 \\
IR (index of intellectual power resources) & 0.080 & 0.254 & 0.199 \\
ER (index of economic power resources) & 0.178 & 0.157 & 0.300 \\
IPR (index of power resources) & 0.215 & 0.360 & 0.424 \\
IPR-2 (extended index of power resources) & 0.237 & 0.432 & 0.490 \\
Mean (of five basic explanatory variables) & 0.162 & 0.316 & 0.319 \\
\hline
\end{tabular}

The application of the second research hypothesis to this sub-group can be tested by regression analysis. As in the case of the global group of 170 countries, regression analysis is restricted to the regression of ID-2001 on IPR. Figure 2 summarizes the results of regression analysis, and the results for single countries are given in Table 5 .

Figure 2 shows that all sub-Saharan countries except Mauritius are at the transition level of IPR from 10 to 20 index scores or below the lower limit of transition. We can see from Figure 2 that there are no deviating nondemocracies above the transition level of IPR. There are several democracies at the transition level of IPR and, as noted above, eight deviating democracies below the transition level of IPR. The ID values of these deviating democracies vary from Benin's 7.2 to Chad's 11.4 (see Table 5). All of them were only slightly above the minimum threshold of democracy in 2001. Figure 2 also shows that the positive correlation between IPR and ID is mainly due to the outlying position of Mauritius. Without Mauritius, the correlation between IPR and ID-2001 is only 0.165 .

The pattern of relationship between IPR and ID is approximately the same in the global group of 170 countries and in this sub-group of 45 sub-Saharan African countries (see Figures 1 and 2). Consequently, the results of regression analyses for single countries given in Table 5 are also more or less similar. Differences in the residuals and fitted values of ID-2001 are relatively small.

The residuals produced by the regression analysis in the global group of 170 countries make it possible to check whether the average level of democratization in sub-Saharan Africa is higher or lower than expected on the basis of the average relationship (regression line) between IPR and ID-2001. The arithmetic mean of 45 residuals is 0.3 (see column 5 in Table 5), which means 


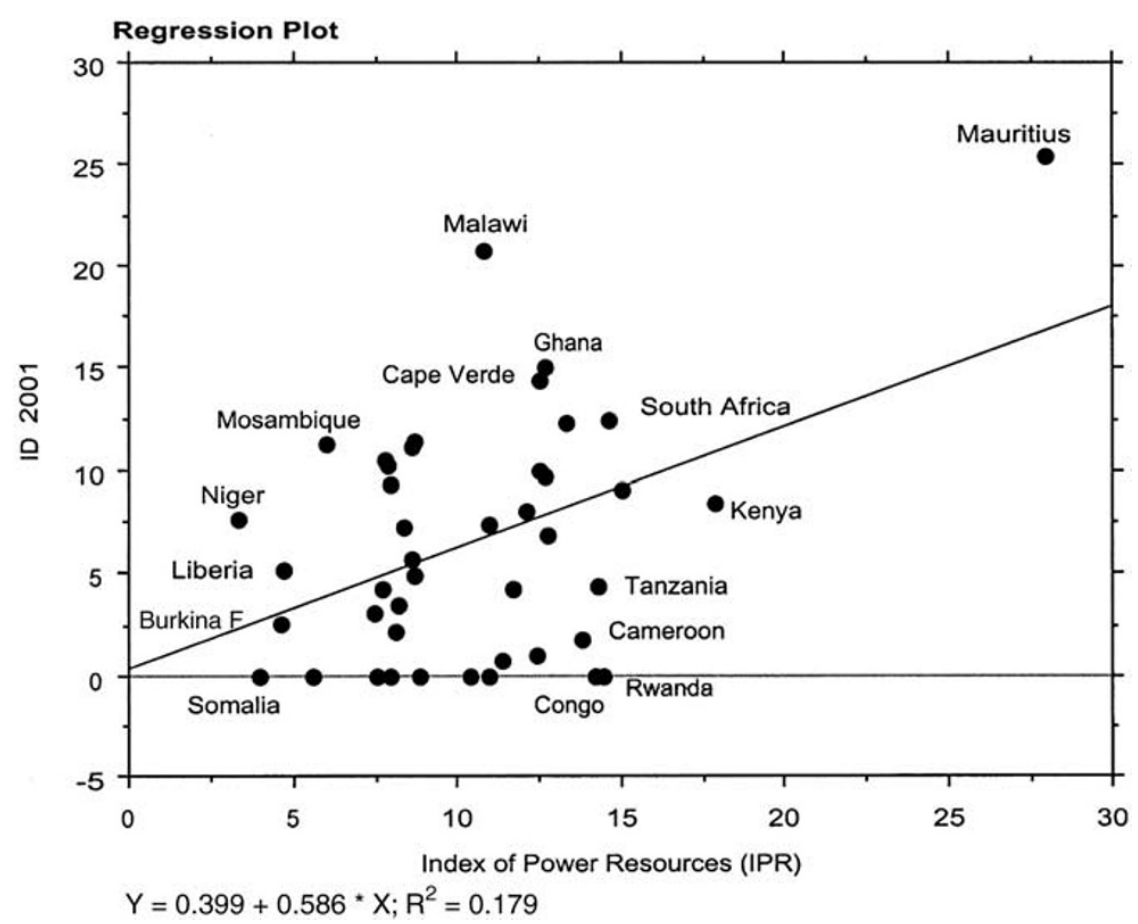

Figure 2 Results of regression analysis of ID-2001 on IPR for single countries in the group of 45 sub-Saharan countries. $y=0.399+0.586\left({ }^{*} x\right) . R^{2}=0.18$.

that the average level of democratization in sub-Saharan Africa is approximately at the expected level. The mean of ID-2001 is 6.5 for the sub-group of 45 sub-Saharan African countries (column 4 in Table 5), and the mean of fitted ID-2001 on the basis of the regression analysis in the group of 170 countries is 6.2 for this sub-group of 45 countries (see column 6 in Table 5). The degree of resource distribution (IPR) explains the average level of democratization in Africa as well as in the other parts of the world. This means, according to my interpretation, that the level of democratization depends principally on the degree of resource distribution in Africa, too. The same common explanatory factor is as relevant for African countries as for the countries of other continents. However, IPR explains only a small part of the variation around the average in this sub-group of 45 sub-Saharan countries.

On the basis of residuals given in Table 5, we can divide the group of 45 countries into three categories: (1) countries with large positive residuals, (2) countries with small and moderate residuals, and (3) countries with large negative residuals. In this classification, the first and third categories include 
Table 5 Results of regression analysis of ID-2001 on IPR in the global group of 170 countries and in the sub-group of 45 sub-Saharan African countries respectively for 45 sub-Saharan African countries

\begin{tabular}{|c|c|c|c|c|c|c|c|c|c|}
\hline & Country & $I P R$ & Com 2001 & Par 2001 & ID 2001 & $\begin{array}{c}\text { Res. ID } \\
\text { global }\end{array}$ & $\begin{array}{l}\text { Fitted } \\
\text { global }\end{array}$ & $\begin{array}{c}\text { Res. ID } \\
\text { Africa }\end{array}$ & $\begin{array}{l}\text { Fitted } \\
\text { Africa }\end{array}$ \\
\hline 1 & Angola & 7.6 & 0 & 0 & 0 & -4.1 & 4.1 & -4.9 & 4.9 \\
\hline 2 & Benin & 8.4 & 32.9 & 21.9 & 7.2 & 1.9 & 5.3 & 1.9 & 5.3 \\
\hline 3 & Botswana & 15.0 & 43.0 & 20.9 & 9.0 & -2.7 & 11.7 & -0.2 & 9.2 \\
\hline 4 & Burkina Faso & 4.6 & 12.5 & 21.2 & 2.6 & 1.6 & 1.0 & -0.5 & 3.1 \\
\hline 5 & Burundi & 10.4 & 0 & 0 & 0 & -5.6 & 5.6 & -6.5 & 6.5 \\
\hline 6 & Cameroon & 13.8 & 7.4 & 23.9 & 1.8 & -6.7 & 8.5 & -6.7 & 8.5 \\
\hline 7 & Cape Verde & 12.5 & 44.4 & 32.4 & 14.4 & 5.5 & 8.9 & 6.7 & 7.7 \\
\hline 8 & Central African R. & 8.6 & 45.5 & 24.5 & 11.1 & 7.1 & 4.0 & 5.7 & 5.4 \\
\hline 9 & Chad & 8.7 & 36.8 & 31.1 & 11.4 & 7.5 & 3.9 & 5.9 & 5.5 \\
\hline 10 & Comoros & 8.9 & 0 & 0 & 0 & -5.6 & 5.6 & -5.6 & 5.6 \\
\hline 11 & Congo & 14.2 & 0 & 0 & 0 & -9.6 & 9.6 & -8.7 & 8.7 \\
\hline 12 & Congo, Dem. Rep. & 11.0 & 0 & 0 & 0 & -6.0 & 6.0 & -6.8 & 6.8 \\
\hline 13 & Cote d'Ivoire & 8.6 & 49.0 & 11.7 & 5.7 & 0.2 & 5.5 & 0.3 & 5.4 \\
\hline 14 & Djibouti & 7.5 & 21.4 & 14.7 & 3.1 & -2.7 & 5.8 & -1.7 & 4.8 \\
\hline 15 & Equatorial Guinea & 12.4 & 2.2 & 44.8 & 1.0 & -6.4 & 7.4 & -6.7 & 7.7 \\
\hline 16 & Eritrea & 10.4 & 0 & 0 & 0 & -4.7 & 4.7 & -6.5 & 6.5 \\
\hline 17 & Ethiopia & 8.2 & 12.1 & 29.2 & 3.5 & 0.2 & 3.3 & -1.7 & 5.2 \\
\hline 18 & Gabon & 12.8 & 30.9 & 22.1 & 6.8 & -4.0 & 10.8 & -1.1 & 7.9 \\
\hline 19 & Gambia & 7.8 & 34.8 & 30.1 & 10.5 & 6.5 & 4.0 & 5.5 & 5.0 \\
\hline 20 & Ghana & 12.7 & 46.5 & 32.2 & 15.0 & 6.9 & 8.1 & 7.2 & 7.8 \\
\hline 21 & Guinea & 8.7 & 21.9 & 22.6 & 4.9 & -0.1 & 5.0 & -0.6 & 5.5 \\
\hline 22 & Guinea-Bissau & 7.8 & 45.3 & 23.2 & 10.5 & 7.5 & 3.0 & 5.5 & 5.0 \\
\hline 23 & Kenya & 17.9 & 47.8 & 17.5 & 8.4 & -1.5 & 9.9 & -2.5 & 10.9 \\
\hline 24 & Lesotho & 11.4 & 2.5 & 28.8 & 0.7 & -7.8 & 8.5 & -6.4 & 7.1 \\
\hline 25 & Liberia & 4.7 & 24.0 & 21.6 & 5.2 & 3.4 & 1.8 & 2.0 & 3.2 \\
\hline 26 & Madagascar & 13.3 & 48.5 & 25.3 & 12.3 & 5.8 & 6.5 & 4.1 & 8.2 \\
\hline 27 & Malawi & 10.8 & 47.6 & 43.8 & 20.8 & 15.6 & 5.2 & 14.1 & 6.7 \\
\hline 28 & Mali & 8.1 & 15.6 & 14.4 & 2.2 & -1.1 & 3.3 & -2.9 & 5.1 \\
\hline 29 & Mauritania & 7.7 & 15.0 & 28.2 & 4.2 & -0.4 & 4.6 & -0.7 & 4.9 \\
\hline 30 & Mauritius & 28.0 & 48.3 & 52.8 & 25.5 & 10.1 & 15.4 & 8.7 & 16.8 \\
\hline 31 & Mosambique & 6.0 & 47.2 & 24.0 & 11.3 & 8.8 & 2.5 & 7.4 & 3.9 \\
\hline 32 & Namibia & 11.0 & 23.5 & 31.6 & 7.4 & -1.5 & 8.9 & 0.6 & 6.8 \\
\hline 33 & Niger & 3.3 & 41.1 & 18.4 & 7.6 & 7.0 & 0.6 & 5.3 & 2.3 \\
\hline 34 & Nigeria & 7.9 & 37.2 & 27.4 & 10.2 & 4.1 & 6.1 & 5.2 & 5.0 \\
\hline 35 & Rwanda & 14.5 & 0 & 0 & 0 & -7.2 & 7.2 & -8.9 & 8.9 \\
\hline 36 & Senegal & 8.0 & 41.5 & 22.4 & 9.3 & 4.5 & 4.8 & 4.2 & 5.1 \\
\hline 37 & Sierra Leone & 5.6 & 0 & 0 & 0 & -2.0 & 2.0 & -3.7 & 3.7 \\
\hline 38 & Somalia & 4.0 & 0 & 1.0 & 0 & -0.9 & 0.9 & -2.7 & 2.7 \\
\hline 39 & South Africa & 14.6 & 33.7 & 37.1 & 12.5 & 1.0 & 11.5 & 3.5 & 9.0 \\
\hline 40 & Swaziland & 8.0 & 0 & 0 & 0 & -8.2 & 8.2 & -5.1 & 5.1 \\
\hline 41 & Tanzania & 14.3 & 19.8 & 22.7 & 4.4 & -3.6 & 8.0 & -4.4 & 8.8 \\
\hline 42 & Togo & 12.1 & 25.2 & 31.7 & 8.0 & 0.6 & 7.4 & 0.5 & 7.5 \\
\hline 43 & Uganda & 12.5 & 30.7 & 32.7 & 10.0 & 3.2 & 6.8 & 2.3 & 7.7 \\
\hline 44 & Zambia & 12.7 & 62.0 & 15.6 & 9.7 & 2.9 & 6.8 & 1.9 & 7.8 \\
\hline 45 & Zimbabwe & 11.7 & 27.8 & 15.5 & 4.3 & -4.0 & 8.3 & -3.0 & 7.3 \\
\hline
\end{tabular}


countries for which both or either one of the two residuals are \pm 5.0 or larger. The countries of the first category are democratic overachievers and the countries of the third category are democratic underachievers. The rest of the countries belong to the second category of countries which deviate only slightly or moderately from the two regression lines. Are there any systematic local or other factors which might explain the differences between these three categories?

\section{Countries with large positive residuals}

Table 5 shows that positive residuals are 5.0. or larger for 12 sub-Saharan African countries: Cape Verde, Central African Republic, Chad, Gambia, Ghana, Guinea-Bissau, Madagascar, Malawi, Mauritius, Mosambique, Niger, and Nigeria. All of them except Niger were above the threshold of democracy in 2001. Niger was slightly below the Participation threshold of democracy. Why is the level of democratization for these countries clearly higher than expected on the basis of IPR? Are there any common explanation for these deviations, or are they due to various local and accidental factors? Let us first examine the state of democracy in each of these countries.

\section{Cape Verde}

This small island country has been above my thresholds of democracy since the 1991 parliamentary election in which the Movement for Democracy won 68\% of the votes and removed the previous hegemonic African Party for the Independence of Cape Verde (PAICV) from power. The PAICV returned to power in the 2001 elections. The new transfer of power took place peacefully. It seems to me that the two competing parties in Cape Verde have learned to accept the results of democratic elections. Peter Meyns (2002) pays attention to the fact that liberation struggle against Portuguese colonialism was not armed one in Cape Verde. As a consequence, it avoided the militarization of society. He says that those "who win power by the bullet are reluctant to forfeit it to the ballot' (p. 156). This is a crucial difference between Cape Verde and Angola, Mosambique, and Guinea-Bissau. Meyns conclusion is that against 'the background of the country's pacted transition, the predominantly moderate outlook of the political parties bodes well for democratic consolidation' (p. 164).

\section{Central African Republic}

Democracy in the Central African Republic is less stabilized than in Cape Verde, although the country has been above the minimum threshold of democracy since the 1993 parliamentary and presidential elections. The actual 
state of democracy seems to be much worse than my electoral variables indicate. Several rebellions have ravished the country, and President Patasse has needed the help of Libya's Muammar Gaddafi to remain in power (see The Economist, 2 November 2002, 44; Internationales Afrikaforum 1/2003, 30). Ethnic cleavages are important in politics. Thomas O'Toole $(1997,120)$ notes that Patasse's regime resembles those of his predecessors in at least two important ways: it relies upon members of his own ethnic group, and it has little relative importance in the daily lives of most of the ordinary people.

\section{Chad}

The country crossed the threshold of democracy first time in the 2001 presidential election, in which President Idriss Deby, the former military ruler, won $63.2 \%$ of the votes cast. In the 1996 election, he had received $71.6 \%$ of the votes, and Chad still remained below the Competition threshold of democracy. Because residuals are highly positive for Chad, a breakdown of democratic institutions would not be unexpected. Bernard Lanne $(1997,282)$ argued that after 30 years of armed conflict, 'the masses of ordinary citizens would probably be satisfied with a stable authoritarian regime that would assure them peace, security, and justice. Among them there is no profound movement in favor of democracy.' The Chadian multiparty system is based on regional and ethnic loyalties. They have provided a social foundation for competitive politics, although parties are still personalist, regional and ideologically shallow, as Roy May and Simon Massey (2002) say. In the 2002 parliamentary election, the ruling Patriotic Salvation Movement won $73 \%$ of the seats (see Inter-Parliamentary Union IPU, 2003).

\section{Gambia}

Gambia had been a democracy since its independence in 1965 until the military coup in 1994, but it was a democracy dominated by one party. The military ruler Yahya Jammeh reintroduced democratic institutions through the 1996 presidential and the 1997 parliamentary elections. In 2001 he became reelected by $53.0 \%$ of the votes cast. Abdoulaye Saine $(2003,375)$ argues, however, that this election 'was riddled with irregularities and problems, ranging from a truncated campaign period designed to favour the incumbent to instances of intimidation and violence against opposition political leaders and supporters. Together, these irregularities rendered the election fundamentally flawed.' Therefore, the real level of democratization in Gambia is probably considerably lower than my measures indicate (cf. Saine, 2002). In fact, the country dropped below the threshold of democracy in the 2002 parliamentary election, which was boycotted by the opposition (see IPU, 2003). 


\section{Ghana}

The political history of Ghana since independence in 1957 has been turbulent. Democratic experiments have alternated with periods of authoritarian rule. The present transition to democracy started in 1992, and in the 1996 presidential and parliamentary elections the country crossed the threshold of democracy. Democratic institutions survived the transfer of power in the 2000 presidential and parliamentary elections, which implies that democracy is becoming stabilized (cf. Smith, 2002). Joseph Ayee (2002, 149) emphasizes that the 2000 elections 'marked the robustness of Ghana's nascent democracy by the smooth transition from a constitutionally elected government that served two terms of office to another one, whose members belong to the largest opposition party, via the ballot box.' This is an important achievement just like in Cape Verde.

\section{Guinea-Bissau}

Guinea-Bissau was a one-party country since its independence in 1974 until the 1994 elections. An army rebellion and civil war in 1998 paralyzed democratic institutions, but in the 1999 parliamentary and the 2000 presidential elections Guinea-Bissau crossed the threshold of democracy again, although only slightly. The survival of democratic institutions is still questionable (cf. The Economist, 22 December 2001, 46).

\section{Madagascar}

Authoritarian regimes prevailed in Madagascar from 1960 to the 1989 competitive presidential election. The next presidential elections in 1993, 1996, and 2001 were also competitive, but the disagreement on the results of the 2001 election paralyzed the system and caused a civil war. The recount of votes in April 2002 confirmed the victory of Marc Ravalomana, and the defeated former President Ratsiraka fled from the country. In the parliamentary election on 16 December 2002, President Ravalomana's party (Tiako I Madagasikara) won $63 \%$ of the seats (see IPU, 2003; Internationales Afrikaforum 1/2003, 53-54).

\section{Malawi}

Malawi is the most highly deviating democracy in sub-Saharan Africa. It was under the authoritarian rule of President Banda and his Malawi Congress Party from the country's independence in 1964 until the 1994 competitive multiparty elections. Samuel Decalo $(1998,91)$ says that 'Banda ruled Malawi as his own personal fief, unilaterally implementing in the country whatever policies he felt were necessary, and brooking no opposition to his fief.' In the 
end, the ailing President Banda was not any longer able to control his opponents. Besides, global donors began to demand democratization in Malawi, too. In the 1994 presidential election, Baliki Muluzi, the candidate of the new United Democratic Front, ousted Banda from the office (see Decalo, 1998, 98-99) Muluzi became reelected in the 1999 presidential election. The new multiparty system in Malawi is regionally based.

\section{Mauritius}

The most stable democracy in this part of the world is Mauritius. It is the only sub-Saharan African country which has remained in the category of democracies since its independence in 1968. Democratic politics in Mauritius has become adapted to the ethnic heterogeneity of its population. Besides, it is the only sub-Saharan country for which the degree of resource distribution is above the transition level of IPR. So it is a democracy as expected.

\section{Mosambique}

The long civil war in Mosambique ended in a stalemate and political compromise in 1994 when the first multiparty elections were held. The fragile democratic institutions survived the next elections in 1999. Democracy in Mosambique seems to be based on an effective distribution of the means of violence between regionally based political parties. The main opposition party Renamo controls some provinces. Carrie Manning (2001, 140) notes that Mosambique's transition from civil war to peace, 'mediated by an internationally supervised transition to democratic government, has been one of the more successful dual transitions of its kind.' However, there are limits of political reconciliation in Mosambique and limits for Renamo's acceptance of the underlying principles of majoritarian democracy (cf. Weinstein, 2002). Mosambique is not yet a consolidated democracy.

\section{Niger}

Since its independence in 1960, Niger remained under the threshold of democracy until the 1993 competitive elections in which the Alliance of the Forces of Change won power, and the country crossed the threshold of democracy. Myriam Gervais (1997, 104-105) argues that democratic consolidation is difficult in Niger because of the weakness of civil society and that the political struggle has taken place within the traditional political class. In fact, democratic institutions did not become stabilized. There was a military coup in 1996 and a new coup in 1999. The presidential election in July 1999 reestablished constitutional system, but Niger remained below the Participation threshold of democracy. John Uniack Davis and Aboubacar N. Kossomi 
(2001) note that, as 'the second poorest country in the world, Niger poses particular problems for advocates of democracy.' They do not have any special explanation for the tentative success of Niger's democracy, but they refer to some characteristics of political culture, to the role of nongovernmental organizations, and to the political conditionality of foreign aid.

\section{Nigeria}

Just like Ghana, Nigeria has experimented with different constitutional systems, and short democratic periods have alternated with long periods of military rule. The present period of democratic rule started in 1999 when General Olusegun Obasanjo won the competitive presidential election. He became re-elected in the 2003 presidential election. Nigeria has made serious attempts to adapt its constitutional system to the requirements of its ethnically highly heterogenous population. It has been difficult to establish constitutional institutions which satisfy the requirements of the ethnic diversity of the country and make it possible to maintain the unity of the country (see Nmoma, 1995). Democratization has not stopped ethnic conflicts and violences in Nigeria (Ukiwo, 2003).

It is difficult to find any common factors which might explain the significantly higher than expected level of democratization in these countries. The quality of democracy varies in this group of countries. Democracy seems to be best consolidated in countries like Cape Verde, Ghana, and Mauritius, whereas it is more defective and insecure in Central African Republic, Gambia, Guinea-Bissau, Niger, Nigeria, and Madagascar. Large positive residuals predict a decrease in the degree of democratization, but this is more probable in the latter than in the first group of countries. There may be one common factor which explains the higher than expected level of democratization in these countries. All of them, except Cape Verde, are ethnically heterogeneous countries in which ethnic cleavages have become institutionalized to serve the needs of democratic political competition. Ethnic heterogeneity represents a dimension of resource distribution which is not taken into account in my explanatory variables.

\section{Countries with small and moderate residuals}

This intermediate category includes 23 countries: Angola, Benin, Botswana, Burkina Faso, Cote d'Ivoire, Djibouti, Ethiopia, Gabon, Guinea, Kenya, Liberia, Mali, Mauritania, Namibia, Senegal, Sierra Leone, Somalia, South Africa, Tanzania, Togo, Uganda, Zambia, and Zimbabwe. It is common for them that they differ only slightly or moderately from the regression line. In other words, the level of democratization seems to be more or less in balance 
with the degree of resource distribution. Six of them were above the threshold of democracy in 2001: Benin, Botswana, Gabon, Senegal, South Africa, and Uganda. The other 17 countries were more or less below the threshold of democracy, but democratic strivings characterize all of them.

\section{Angola}

The long ethnic civil war has delayed the introduction of democratic politics in Angola (cf. The Economist, 25 May 2002, 45-46). The degree of resource distribution is still so low (IPR 7.6) that we cannot expect democratization on the basis of regression equations (fitted ID values are 4.1 and 4.9), although negative residuals predict some kind of democratization. The fighting ended in 2002 , but the process of reconciliation has been slow, and the country is still without a new constitution (see Internationales Afrikaforum 1/2003, 44; Africa Confidential, 18 April 2003). However, the ethnic heterogeneity of the population provides a potential social basis for democratic politics.

\section{Benin}

The degree of resource distribution seems to be in Benin nearly as low as in Angola, but Benin has been a democracy since the 1991 parliamentary and presidential elections, and its positive residuals are small. Politics in Benin has become adapted to its social circumstances, although after the 2001 elections the country is only slightly above the threshold of democracy. Samuel Decalo (1997) emphasizes the ethnic basis of all politics in Benin. As noted above, ethnicity represents one dimension of resource distribution which is not taken into account in my IPR. The problem is how to acommodate ethnic cleavages into democratic political competition. Some countries have succeeded in it; some others have failed.

\section{Botswana}

Botswana has been just above or slightly below the threshold of democracy since its independence in 1966. The stability of its political system is based on the dominance of the ruling Botswana Democratic Party, which is supported by the largest and dominant ethnic groups. The level of democratization is in balance with the degree of resource distribution.

\section{Burkina Faso}

There has been struggle for democracy and attempts to establish democratic institutions, but Burkina Faso has not yet been able to cross the threshold of democracy. Its present authoritarian system modified by some democratic institutions is in balance with the low degree of resource distribution. 
According to Laura E. Boudon (1997, 140), the 'available evidence suggests that though Burkina Faso still falls short of even the minimalist ideal, it is finally moving in the right direction,' but it faces a long and difficult road ahead. A positive characteristic in Burkina Faso is that, despite the existing Mossi dominance, 'it does not suffer from cronic ethnic or religious strife.' In fact, the 2002 parliamentary election was highly competitive (see IPU, 2003).

\section{Cote d'Ivoire}

The present civil war in Cote d'Ivoire is connected with the struggle for democracy. The country had a stabilized authoritarian system during the long period of Felix Houphouet Boigny's presidency from 1960 to 1995, but his successor was not any longer able to maintain the one-party system. There was a military coup in 1999. The inconclusive 2000 presidential election was followed by violent demonstrations and ethnic fighting (see Toungara, 2001; The Economist, 28 September 2002, 46; Internationales Afrikaforum 1/2003, 2123), which continued at least to the cease-fire made in May 2003 (Helsingin Sanomat, 5 May 2003). Cote d'Ivoire illustrates the situation in which power resources are sufficiently distributed to undermine the survival of a hegemonic political system, but in which contestants are not yet convinced that it is necessary to agree on the sharing of power. Robert J. Mundt (1997, 182) succinctly notes that 'democratization grows out of erosion of power and stalemate.' The multiparty system that emerged in the $1990 \mathrm{~s}$ is ethnically based (see Toungara, 2001).

\section{Djibouti}

Djibouti has never crossed the threshold of democracy, although there have been elections since its independence in 1977. Its present semi-democratic system seems to be in balance with a low degree of resource distribution. However, there is a political opposition which strives to establish a more democratic system. The majoritarian system of elections makes it difficult for opposition parties to win any seats in the parliament (see Internationales Afrikaforum 1/2003, 46-47).

\section{Ethiopia}

The slow process of democratization started in Ethiopia in 1995 when winners of the civil war introduced the country's present constitutional system. There has been some competition in elections, but power is concentrated in the hands of the ruling Ethiopian People's Revolutionary Democratic Front. Such a system of authoritarian rule seems to be in balance with a low degree of resource distribution. 


\section{Gabon}

Gabon has had competitive elections since 1990, but the country is only slightly above the minimum threshold of democracy. Democracy in Gabon is constrained by the dominance of the Gabonese Democratic Party and the hegemonic position of President Omar Bongo. Such a semi-democratic system has become adapted to a low degree of resource distribution. Its multiparty system is ethnically based (cf. Gardinier, 1997). In Gabon, ethnicity and regionalism have gone hand-in-hand. Every ethnic group found itself in the forest areas 'has seen itself discriminated against by the ruling elite, identified as Fang-Mpomgwe or Teke' (Azevedo, 1995, 281; cf. Decalo, 1998).

\section{Guinea}

The struggle for democracy led to the introduction of competitive elections in 1993. Guinea crossed the threshold of democracy in 1995, but in 2000 it dropped again below the threshold because parliamentary elections were postponed until an unspecified later date. Such a semi-democratic system was in harmony with the country's low degree of resource distribution (residuals -0.1 and -0.6). In the new legislative election in 2002, Guinea crossed the threshold of democracy, although the ruling Party of Unity and Progress won $74.6 \%$ of the seats in the National Assembly.

\section{Kenya}

The struggle for democracy has continued in Kenya since its independence in 1963. The fact that IPR (17.9). for Kenya is higher than for any other continental sub-Saharan African country explains the strong support of opposition groups in the country. Multiparty elections were introduced in 1992, and Kenya crossed the threshold of democracy, but in 1997 it dropped slightly below the Participation threshold of democracy. According to my measures, the degree of resource distribution is high enough to support democratic politics. Kenya crossed the Competition threshold of democracy in the 2002 elections, but remained slightly below the Participation threshold. Competitive politics in Kenya was previously based on ethnic affiliations. Githu Muigai (1995, 160-161) says that in the absence 'of other platforms upon which to base political appeal ethnicity presents itself as the most natural basis of political organization.' In the 2002 elections, the importance of ethnic affiliations decreased to some extent because the two major parties had to compete for votes in all regions of the country (see Anderson, 2003).

\section{Liberia}

After a bloody civil war, Liberia returned to a constitutional system in 1997 by competitive parliamentary and presidential elections. Since then politics in 
Liberia has been dominated by Charles Taylor and his National Patriotic Party. The country is below the threshold of democracy, but residuals are slightly positive, which implies that we cannot expect further democratization. In fact, a civil war continues in Liberia (see The Economist, 9 November 2002, 44; Internationales Afrikaforum 1/2003, 20-21).

\section{Mali}

The limited degree of democratization seems to be in balance with the low degree of resource distribution. President Konare won the 1997 presidential election by $84.4 \%$ of the votes cast. Mali has not yet crossed the Participation threshold of democracy, but it crossed the Competition threshold in the 2002 presidential election in which the support of opposition candidates rose to $35 \%$. According to Zeric Kay Smith (2001), Mali has remained democratic since its first multiparty elections in 1992. He notes that Mali's successful democracy runs counter to most theories about the effects of economic underdevelopment, ethnic heterogeneity, and income inequality. As an explanation, he refers to 'a unique political culture that may have provided Mali with a democratic advantage over other African nations,' but also to the leadership of President Alpha Oumar Konare. The 2002 National Assembly elections were highly competitive and strengthened democracy in Mali (see IPU, 2003).

\section{Mauritania}

Mauritania is a semi-democracy with competitive elections which have not endangered the dominant position of the ruling party. Boubacar N'Diaye (2001) says that President Ould Taya "conducted a methodical, military-style operation that legitimized his regime without altering its essential features and thus risking the loss of power.' The fact that the country is geographically and culturally on the borders of arabized North Africa and sub-Saharan Africa characterizes politics in Mauritania. The deep ethnic cleavage between ArabBerber Moors and black tribal groups makes the peaceful sharing of power difficult. The Moor community is dominant in politics. The Democratic and Social Republican Party, based on the support of the Moors, is the predominant party. Elections are competitive, but the government has controlled the opposition by authoritarian methods. Marianne Marty concludes that 'democracy is still not truly established' (Marty, 2002, 106).

\section{Namibia}

Despite its competitive political system, Namibia has not been able to cross the Competition threshold of democracy. President Sam Nujoma and his party 
South West Africa People's Organization (SWAPO) dominate politics. Such a semi-democratic system is in balance with a low degree of resource distribution (residuals -1.5 and 0.6). Despite SWAPO's dominance, opposition parties have been able to retain their support mainly in the regions of some minority ethnic groups and in urban areas (see Lodge, 2001).

\section{Senegal}

The process of democratization in Senegal started already in 1978 when opposition parties were allowed to participate in elections. Senegal crossed the Competition threshold of democracy in the 1993 presidential election, but it has not yet been able to cross the Participation threshold, except temporarily in 2001 when a national referendum raised Participation slightly above the $20 \%$ threshold. Richard Vengroff and Lucy Creevey (1997) describe Senegal as a quasi democracy. According to them, political reform 'in Senegal has been an evolutionary process that has moved the nation to the brink of full democracy' (p. 216). The presidential and legislative elections in 2000 signified a crucial step toward a full democracy. The Senegalese Democratic Party replaced the Socialist Party as the dominant party in the National Assembly, and its presidential candidate Abdoulaye Wade 'defeated 19-year incumbent Abdou Diouf of the Socialist Party in the second round of the presidential election' (Galvan, 2001, 51). It is remarkable that the two leading parties are not clearly ethnically based. According to Dennis Galvan (2001, 60), they 'continue to rely patronage to attract and mobilize followers, whether by providing publicsector jobs or by dispensing food and clothing at rallies'. Ethnic rebellion in the Casamance region continues (Internationales Afrikaforum 1/2003, 17-18).

\section{Sierra Leone}

It has been difficult for competing parties and tribal groups to agree on democratic rules of power sharing. Democratic institutions failed several times, and politics degenerated into civil war. The period of temporary governments and civil war continued from 1997, when President Kabbah was violently overthrown, to the new parliamentary and presidential elections on 14 May 2002 (see The Economist, 18 May 2002, 45). The country remained still slightly below the Competition threshold of democracy, but residuals turned positive. Because the degree of resource distribution is extremely low in Sierra Leone, it will be very difficult to stabilize democratic institutions.

\section{Somalia}

During the first years of independence, Somalia maintained a democratic system and was a highly deviating democracy. My explanatory variables 
predicted the downfall of democracy. It happened in 1969 when General Siad Barre usurped power. Since then Somalia has been a non-democracy, and since 1991, when Siad Barre was overthrown, without any effective national government. The extremely low degree of resource distribution (IPR 4.0) predicts an authoritarian system. In Somalia, ethnic conflicts take the form of clan conflicts. Hussein M. Adam (1995, 197-198) notes that the civil wars 'have escalated clan conflicts to the level of the clan-families transforming these, perhaps temporarily, to entities resembling 'nationalities'.

\section{South Africa}

South Africa had a competitive party system during the long period of the white minority rule, but because the black majority was excluded from politics, the country remained below the Participation threshold of democracy. South Africa crossed the threshold of democrary in the 1994 competitive parliamentary elections and has remained above the threshold since then. The African National Congress dominates politics, but until now the combined share of other parties has remained above the 30\% threshold of democracy. The present level of democratization is in balance with the degree of resource distribution in South Africa (residuals 1.0 and 3.5). The ethnic diversity of the population represents the greatest challenge for democracy in South Africa, but Vincent T. Maphai $(1995,112)$ argues that if 'liberal democracy fails in South Africa, this will have less to do with ethnicity and much more to do with economic and social redistribution' (see also Gilliomee et al., 2001).

\section{Tanzania}

Since its independence in 1961, Tanzania has been dominated by one party, the Revolutionary Party of Tanzania. A slightly more competitive system was introduced in the 1995 parliamentary and presidential elections, but the same ruling party has been able to remain in power, and the country is still slightly below the threshold of democracy. Its clearly negative residuals $(-3.6$ and -4.4) imply that Tanzania has some chances to cross the threshold of democracy in the next elections. With an estimated 120 languages Tanzania is one of the most ethnically diverse countries in sub-Saharan Africa, but because all tribal groups are small, Tanzania has avoided large scale ethnic mobilization in politics. There is no dominant ethnic group, and parties demonstrate no clear ethnic ties (see Glickman, 1995b).

\section{Togo}

President Eyadema was long able to retain his hegemonic position by a combined strategy of co-optation and repression (see Heilbrunn, 1997), but the 
2002 presidential election was highly competitive, and the country became a semi-democracy as expected on the basis of the regression analysis. Because of the complete dominance of the President Eyadema's Togolese People's Rally, the country is still slightly below the Competition threshold of democracy. The process of democratic consolidation is slow in Togo (cf. Internationales Afrikaforum 1/2003, 24-25).

\section{Uganda}

Uganda crossed the threshold of democracy first time in the 2001 presidential election in which General Yoweri Museveni received $69.3 \%$ of the votes. This kind of one-party dominated limited democracy is in balance with a relatively low degree of resource distribution. The political system established by Museveni seems to be relatively well adapted to the circumstances of Uganda. However, people demand the legalization of political parties.

\section{Zambia}

Zambia's political system has been partly competitive since its independence in 1964, although the country has never crossed the threshold of democracy. The most radical change took place in 1991 when the Movement for Multiparty Democracy (MMD) replaced President Kaunda's United National Independence Party as the ruling party and Frederick Chilubu became elected president. However, the new party's victory was so overwhelming that the country remained below the threshold of democracy. The 2001 elections were highly competitive, and Zambia crossed the Competition threshold of democracy, but still remained below the Participation threshold (see The Economist, 5 January 2002, 33-34). The disunity of opposition parties helped the ruling MMD to remain in power (see Burnell, 2003). The opposition parties in Zambia have not yet learned to form a coalition in elections.

\section{Zimbabwe}

A democratic constitutional system was introduced in 1980 when Zimbabwe achieved independence after a long period of civil war. At first Zimbabwe was clearly above the threshold of democracy, and its positive residuals were large, but in the 1985 parliamentary elections, in which the ruling ZANU party received $76.3 \%$. of the votes, it dropped below the threshold of democracy. President Robert Mugabe dominates politics in Zimbabwe. The struggle for democracy has intensified, and the government has had to resort to violent means in order to remain in power. President Mugabe became reelected in the 2002 presidential election (see The Economist, 16 March 2002, 29-31), but 'only after the regime deployed tactics whose sheer brutality and underhandedness 
were without precedent even in the troubled postindependence history of this southern African republic of 11.4 million people' (Makumbe, 2002, 87). Masipula Sithole $(1995,121)$ notes that Zimbabwe has never foreclosed multiparty electoral opportunities, but it has constrained them by maintaining or perpetuating a one-party political psychology. Now the opposition seems to have grown so strong that it may break this tradition.

It is characteristic for these 23 countries that the level of democracy deviates relatively little from the regression lines. There are democratic strivings in practically all of these countries, although most of them are still below the threshold of democracy. For most of them, the degree of resource distribution (IPR) seems to be still too low to generate democracy or to support democratic institutions. Most of them have suffered from ethnic conflicts, and some also from ethnic civil wars (especially Angola, Cote d'Ivoire, Liberia, Mauritania, Sierra Leone, Somalia, South Africa, Uganda, and Zimbabwe). In some cases ethnic conflicts have stalemated democratization, or caused breakdowns of democratic institutions, but there are also cases in which multiparty systems have become accommodated to existing ethnic affiliations. Because these countries deviate only slightly or moderately from the regression lines, it is not justified to predict any drastic changes on the basis of resource distribution. In this group of countries, various local, external, and accidental factors seem to explain the variation in the degree of democratization (ID) around the regression lines.

\section{Countries with large negative residuals}

The category of countries with large negative residuals ( -5.0 or higher) includes ten countries: Burundi, Cameroon, Comoros, Congo, Democratic Republic of Congo, Equatorial Guinea, Eritrea, Lesotho, Rwanda, and Swaziland. Why are their political systems much more authoritarian than expected on the basis of resource distribution and the regression analysis? That is the problem. Is there any common explanation for the lack of democracy in these countries, or are the causes unique in each case?

\section{Burundi}

The deep ethnic conflict between the tribal groups of Hutus and Tutsis has prevented all attempts to establish democratic institutions. The ruling Tutsi minority has not been willing to share power democratically with the Hutu majority. The introduction of democracy would transfer power from the Tutsi minority to the Hutu majority. Until now the Tutsis have been able to maintain their hegemony. The struggle for power and democracy has been violent from time to time. The military junta led by Major Pierre Buyoya has been in power 
since the coup on 25 July 1996. On 30 April 2003, he ceded the presidency to Vice-President, Domitien Ndayizeye, a Hutu, but the civil war continues (see Africa Confidential, 13 September 2002; The Economist, 10 May 2003). It was a small step toward power sharing.

\section{Cameroon}

The struggle for democracy has been intensive in Cameroon since its independence in 1960. The country crossed the threshold of democracy temporarily in 1992 when Paul Biya was elected president by $60 \%$ of the votes cast. However, in the next presidential election in 1997, Cameroon dropped again below the threshold of democracy when President Biya was reelected with $92.6 \%$ of the votes. Serious regional and tribal conflicts have made it difficult to introduce competitive and free elections. Joseph Takougang (1997, 178) stresses that President Biya "has been reluctant to allow any changes that went beyond the limited political framework he envisioned for the nation, especially if they threatened his continued stay in power.' Besides, opposition parties have failed to sustain a well-coordinated challenge to Biya (see also Azevedo, 1995).

\section{Comoros}

The small island state Comoros has experienced several violent coups. A democratic system was established in 1990 when Said Mohammed Djohar was elected president $(55.3 \%)$. in the country's first contested presidential election. Before that the former President Abdallah had been killed in 1989, and he was succeeded, on an interim basis, by Djohar as the president of the Supreme Court. A military coup ousted President Djohar in September 1995, but the country crossed again the threshold of democracy in 1996 when Mohamad Taki Abdulkarim was elected president by $61.2 \%$ of the votes. After the dead of President Abdulkarim on 6 November 1998, the government was unable to organize a new presidential election. Military governments have ruled the country since 1999. The election of Azali Assoumani president without opposition in 2002 did not improve the situation. There is social potential for a more democratic rule in Comoros.

\section{Congo (Brazzaville)}

Since its independence in 1960, Congo (Brazzaville) has been ruled by authoritarian presidents and military governments, but not without opposition and democratic strivings. Political struggles have been mixed with tribal conflicts. In 1991, the National Conference representing 30 parties and 141 associations approved a new democratic constitution. A coalition of 
opposition groups was able to win parliamentary and presidential elections in 1992. John F. Clark (1997b, 78-79) attributed the relative success of democracy in Congo to the choices made by individual actors and to the statemanship at crucial moments. Congo was above the threshold of democracy until 1997 when the former president Sassou-Nguesso seized military control after four months of civil war and declared himself president (see Clark, 2002). The fighting has continued between the army and tribal rebels (see The Economist, 15 June 2002, 46). Sassou-Nguesso legalized his power through a presidential election on 10 March 2002, but the country still remained below the Competition threshold of democracy, although negative residuals decreased.

\section{Congo, Democratic Republic of}

All attempts to establish a democratic system have failed until now in the Democratic Republic of Congo (former Zaire). The central government has been unable to rule the extensive area of Congo effectively. Insurgents led by Laurent Kabila entered Kinshasa on 16 May 1997 and ousted Mobuto, but the dictatorship and civil war has continued. Some parts of the country are ruled by rebels (see The Economist, 6 July 2002, 39-41; Internationales Afrikaforum, 1/2003, 32-34). Thomas Turner (1997) says about the Mobuto regime that it was kleptocratic and that coercion was a major tool of governance in Zaire. The change of dictator in 1997 does not seem to have changed the nature of the regime. Considering the poor state of communications, it is reasonable to argue that the geographical area of the Democratic Republic of Congo is too extensive for one national government (cf. Clark, 1995). There is no national party or political organization in Congo. All parties have been limited to some region or ethnic group (see Carey, 2002).

\section{Equatorial Guinea}

Equatorial Guinea experienced an extremely cruel dictatorship of Francisco Macias Nguema from 1968 to a coup d'etat in 1979, and has since then been ruled by Colonel Theodoro Obiang Nguema. There are numerous opposition parties and groups, but they have until now been unable to challenge to hegemony of President Obiang and his ruling Democratic Party of Equatorial Guinea. President Obiang Nguema became reelected in December 2002 by 97\% of the votes (Internationales Afrikaforum, 1/2003, 31).

\section{Eritrea}

Eritrea has been ruled by the transitional government of the People's Front for Democracy and Justice since its independence in 1993. The party's General Secretary Isaias Afwerki was proclaimed president of Eritrea. The 
governmental party has been unwilling to share power with predominantly Muslim opposition groups and to introduce competitive elections.

\section{Lesotho}

Lesotho started its independence with a democratic constitution in 1966, and the country remained above the threshold of democracy until 1969 when Prime Minister Jonathan usurped power. Since then Lesotho was a long time below the threshold of democracy and sometimes it was ruled by military governments. However, Lesotho recrossed the threshold of democracy through the 2002 parliamentary election, in which the ruling party (Lesotho Congress for Democracy) did not get more than $64.2 \%$ of the seats. Large negative residuals disappeared.

\section{Rwanda}

The ethnic conflict between the Tutsi minority and and the Hutu majority has several times led to ethnic violences and extreme cruelties. Despite its small size, the country has never been able to establish a democratic government. Since the 1994 orgy of killing, Rwanda has been ruled by the transitional government of the Tutsi dominated Rwandan Patriotic Front. According to Timothy Longman $(1997,301)$, the impact of the massacres and the civil war on Rwanda's political system, economy, and society appears likely to endure for a long time, as intense insecurity, authoritarian rule, and severe poverty continue to plague the country.' The French government was partly responsible for the massacres of 1994. Longman (1997, 302) argues that without French support, the Habyarima government 'might have found it necessary to accept a compromise with both the parties of opposition and the RPF that could have avoided the massacres and ended the civil war'.

\section{Swaziland}

Executive and legislative powers are in the hands of the traditional king and his relatives. In this respect Swaziland is unique among sub-Saharan African countries. There are several opposition parties and groups which demand democratic reforms. The pressure for democratic reforms is growing (see Africa Confidential, 27 September 2002).

There are democratic strivings in all these countries with large negative residuals. Some of them (Cameroon, Comoros, Congo-Brazzaville, and Lesotho) have been temporarily above the threshold of democracy. For various local reasons democratic experiments have failed and the level of democratization is much lower than expected. It is common for eight of these countries, except Lesotho and Swaziland, that they have experienced serious 
ethnic conflicts and even ethnic civil wars. It is evident that ethnic groups and other contestants have not been able to compromise and to agree on the sharing of power through elections. In this respect, the worst situation is in Burundi, the Democratic Republic of Congo, Equatorial Guinea, Eritrea, and Rwanda. Congo (Brazzaville) has become partly democratized. Lesotho returned to the category of democracies through competitive parliamentary election in 2002, and its large negative residuals disappeared. Swaziland is an exceptional absolute monarchy. Some kind of democratization in Swaziland would not be unexpected.

\section{Discussion}

Many researchers have explored the problem of democratization in sub-Saharan Africa and presented different explanations for the success or failure of democracy. I refer to some recent studies. Harvey Glickman argues that African politics remain severely divided by ethnic conflict, but 'ethnic conflict is not incompatible with institutions of democratic government if it finds expression as a group interest among other interests' (Glickman 1995a, 3). I agree with this argument. According to John F. Clark (1997a, 28), the most basic constraint on the consolidation of democratic regimes in Africa is underdevelopment itself. My point is that underdevelopment represents a specific aspect of low level of resource distribution. Samuel Decalo (1998, 273302) examines factors behind the democratic upheavals in Africa and pays attention to both internal and external factors, including the impact of the sudden collapse of Marxism in Eastern Europe and powerful international demands for better governance, democratization, and a free economy. He comes to the conclusion that the process of democratization will be slow, and backslidings into political strife, social chaos, and single-party and military rule are also possible.

Naomi Chazan et al. (1999) do not make any predictions on the prospects for democracy in Africa. They emphasize that the 'fluidity of African politics and the variety of responses to the problems that have emerged since independence make any effort to predict the future extremely hazardous' (p. 491). However, they point out that the failure 'of early democratic experiments highlights the importance of strengthening the social foundations, and not only the institutional frameworks, of liberal government' (p. 494). I agree. The success or failure of democratization depends ultimately on the nature of social foundations. Obioma M. Idehuru (1999) focuses on the impact of structural adjustment policies on democratization. One of his findings is 'that structural adjustment leads to the evolution of civil society through the formation of groups,' and, 'through activating civil society, structural 
adjustment also leads to democratization' (pp. 105-113). Consequently, he comes to the conclusion that 'in the final analysis the full implementation of structural adjustment would have the capacity to put in place auspicious conditions for meaningful democratization in Africa in the next millenium' (p. 128). I would like to point out that 'the evolution of civil society through the formation of groups' means the distribution of important power resources among competing groups in a society.

Christopher Fomunyoh (2001) says that the struggle for democratization in Francophone Africa has witnessed the emergence both of significant grassroots initiatives and of important constitutional reforms and institutional innovations, including the vital role of civil society organizations in multiparty elections, the creation of independent election commissions, and the empowerment of legislators. On the other hand, various hurdles, including flawed elections, poorly managed civil-military relations, weak political parties, and partisan bureaucracies, continue to hinder democracy's advance. His conclusion is that the people of Francophone Africa seem committed to furthering democracy.

Nicolas van de Walle (2002) emphasizes that 'the typical sub-Saharan country is measurably more democratic today than it was in the late 1980s,' although the nature of polities varies 'from relatively liberal democracies to thinly veiled personal dictatorships' (pp. 67-68). He notes that in most African countries, 'power lies with a president and a small ruling circle who use the state's resources to keep the support of large networks of political clients' (p. 69). This description illustrates the way how economic power resources are used in politics. He does not find any convincing theoretical explanation for political variations among African countries. Modernization theory is not much of help because there is so little socioeconomic variation across the region. The capacity of 'the donors' to further democratization is limited. $\mathrm{He}$ comes to the conclusion that 'since structural variables have little explanatory power when countries are so similar socioeconomically yet so different politically,' we should 'acknowledge that political outcomes will depend to no small degree on what important individuals think, do, and say' (p. 79). I agree that personal factors matter and may explain a part of the variation.

My attempt to explain democratization in sub-Saharan Africa differs from those of others in one important respect. I argue that there is one causal factor of democratization (resource distribution) which explains democratization equally well in all parts of the world. The results of correlation and regression analyses support strongly this theory of democratization. In the global group of 170 countries, the degree of resource distribution as measured by IPR explains $72 \%$ of the variation in the degree of democratization as measured by ID in 2001. There are deviant cases that contradict the hypotheses, but their number is relatively small compared to the number of countries that deviate 
from the regression line only moderately. I want to emphasize that the operationally defined variables of this study are not complete substitutes for the hypothetical concepts of 'democratization' and 'resource distribution.' They measure only some aspects of hypothetical concepts, and they certainly include measurement errors. Therefore, the true relationship between democratization and resource distribution may be even stronger than correlations indicate, but because there are also other significant factors affecting democratization, the relationship between the degree of resource distribution and democratization can never become complete.

It is remarkable that the average relationship between IPR and ID-2001 seems to apply approximately as well to sub-Saharan African countries as to the countries of other regional groups. Only few African countries deviate greatly (residuals \pm 8.0 or higher) from the regression line. The low degree of resource distribution explains the lack of democracy in most sub-Saharan African countries and leads to the prediction that it is not reasonable to expect any drastic changes in the near future.

The examination of sub-Saharan African countries implies that even a low degree of resource distribution is enough to provide a social basis for democratic strivings, although it may not be enough to establish and maintain democratic institutions. The existence of numerous legal or illegal political parties and groups in all these countries indicates the desire of African people to participate in national politics through their own parties and other interest groups. It is obvious that there are no cultural inhibitions against democratic politics in Africa. Democracy is an expression of the universal human disposition to compete for power because power can be used to further one's own interest in the continual struggle for scarce resources. Democracy provides an institutional framework to share power among competing individuals and groups through competitive elections. According to my theory, such a system of institutionally shared power become established as soon as power resources are so widely distributed that no single group is not any longer able to establish or maintain its hegemony. In most African countries, this situation has not yet been achieved because a low degree of resource distribution makes it still possible for single groups to usurp power and to suppress opposition or at least to establish and maintain hegemonic or semi-democratic systems. However, the struggle for democracy continues in all parts of Africa, and people attempt to introduce democratic institutions. John F. Clark (1997a, 25) points out that the authors of his volume 'take seriously the idea that some African political leaders and ordinary citizens have actually been struggling for democracy, rather than merely against certain authoritarian regimes and dictatorial leaders.'

My point is that the fundamental causal factor behind democratization is resource distribution, not the level of economic development, foreign pressure, 
or some other factor. I think that economic development is only a special case of resource distribution. It furthers democratization to the extent that it causes socioeconomic power resources to become more widely distributed among various sectors of the population. Usually, economic and also intellectual power resources are more widely distributed in economically highly developed countries than in less developed countries, but there are significant exceptions to this rule. Democracy is possible also in poor countries in which important power resources are sufficiently distributed among competing groups. In subSaharan Africa, the extension of education would further the distribution of intellectual power resources and thus strengthen the social basis of democratic political competition. The introduction and support of the institutions of market economy would distribute the control of economic power resources, increase the economic freedom of people, and decrease opportunities and need for corruption. The extension of private ownership of agricultural land might also be useful because it would consolidate the economic and social independence of rural people and thus give them better chances to take part in national politics.

The existence of deviating cases indicates that resource distribution as measured by my variables cannot be regarded as the only factor explaining the variation in the level of democratization. Deviating cases imply the impact of other causal factors. In sub-Saharan Africa, those other factors may include ethnic factors in particular, but probably also various other factors. I have not attempted to explore those other factors or to measure their relative significance. Researchers specialized to regional studies are better qualified to seek out and to evaluate their significance. My argument is that despite the impact of various other factors, the degree of resource distribution is able to explain quite satisfactorily the low level of democratization in most sub-Saharan African countries (see Figure 1), although it does not explain the variation around the regression line in this sub-group of countries (see Figure 2).

In addition to ethnic factors, this variation seems to be due to personal factors (political leaders), accidental factors, external factors, and to some extent also to socioeconomic development. Personal factors vary more or less accidentally. Some political leaders support democracy; some others prefer authoritarian structures. External factors (collapse of European socialist systems and international pressure for good governance) contributed to the emergence of democratic strivings in the end of the 1980a and in the beginning of the 1990s and to attempts to establish and maintain more democratic systems than what was possible in the social circumstances of sub-Saharan African countries. John F. Clark (1997a, 33) notes that it "can hardly be an accident that the recent wave of democratization in Africa, which peaked in 1991 or 1992, ensued immediately after the collapse of Eastern Europe's 
communist regimes.' In the case of Tanzania, for example, the pressure applied by donor states seems to have been a major factor which prompted Tanzania's political leadership to introduce democratic reforms in the 1990s (see Vener, 2000). Tanzania is not the only one of such cases. My argument is that a high level of socioeconomic development is not a necessary precondition for democratization, although it certainly is a useful factor. The fact is that democratic systems have been established in many extremely poor sub-Saharan African countries. According to my intrepretation, democracy is possible also in poor countries if important power resources are sufficiently distributed among competing groups.

Ethnicity is probably the most important of those other factors affecting democratization in sub-Saharan Africa. In some countries ethnic cleavages have provided a solid basis for democratic party competition; in some other cases ethnic interest conflicts have accelerated into violences or attempts to establish ethnic hegemonies. As a consequence, there is only a weak relationship between ethnic heterogeneity of the population and the level of democratization (ID). In this group of 45 sub-Saharan African countries correlation between my Index of Ethnic Heterogeneity (see Vanhanen, 1999a, b) and the Index of Democratization in 2001 is positive but not higher than 0.307. The appearance of positive relationship indicates that ethnic heterogeneity is not always and necessarily detrimental to democratization. The problem is how to institutionalize the resource distribution in the form of ethnic cleavages to generate and maintain democratic competition for power.

\section{References}

Adam, H.M. (1995) 'Clan Conflicts and Democratization in Somalia', in H. Glickman (ed.) Ethnic Conflict and Democratization in Africa, Atlanta, GA: The African Studies Association Press.

Africa Confidential (2002), London: Africa Confidential.

Africa Confidential (2003), London: Africa Confidential.

Alexander, R.D. (1980) Darwinism and Human Affairs, London: Pitman Publishing.

Anderson, D.M. (2003) 'Briefing: Kenya's Elections 2002-the dawning of a new era?', African Affairs 102: 331-342.

Arat, Z.F. (1991) Democracy and Human Rights in Developing Countries, Boulder, CO: Lynne Rienner Publishers.

Ayee, J. (2002) 'The 2000 general elections and presidential run-off in Ghana: an overview', Democratization 9(2): 148-174.

Azevedo, M. (1995) 'Ethnicity and Democratization: Cameroon and Gabon', in H. Glickman (ed.) Ethnic Conflict and Democratization in Africa, Atlanta, GA: The African Studies Association Press.

Berg-Schlosser, D. and Mitchell, J. (eds.) (2000) Conditions of Democracy in Europe, 1919-39: Systematic Case Studies, London: Macmillan Press.

Boudon, L.E. (1997) 'Burkina Faso: The 'Rectification' of the Revolution', in J.F. Clark and D.E. Gardinier (eds.) Political Reform in Francophone Africa, Boulder, CO: Westview Press. 
Bruce, J.W. (1998) Country Profiles of Land Tenure: Africa, 1996, LTC Research Paper No. 130. Land Tenure Center, University of Wisconsin, Madison.

Burnell, P. (2003) 'The tripartite elections in Zambia, December 2001', Electoral Studies 22: 388-395.

Carey, S.C. (2002) 'A comparative analysis of political parties in Kenya, Zambia and the Democratic Republic of Congo', Democratization 9(3): 53-71.

Chazan, N., Lewis, P., Mortimer, R., Rotchild, D. and Stedman, S.J. (1999) Politics and Society in Contemporary Africa (3rd edn), Boulder, CO: Lynne Rienner Publishers.

Clark, J.F. (1995) 'Ethno-Regionalism and Democratization in Zaire', in H. Glickman (ed.) Ethnic Conflict and Democratization in Africa, Atlanta, GA: The African Studies Association Press.

Clark, J.F. (1997a) 'The Challenges of Political Reform in Sub-Saharan Africa: A Theoretical Overview', in J.F. Clark and D.E. Gardinier (eds.) Political Reform in Francophone Africa, Boulder, CO: Westview Press.

Clark, J.F. (1997b) 'Congo: Transition and the Struggle to Consolidate', in J.F. Clark and D.E. Gardinier (eds.) Political Reform in Francophone Africa, Boulder, CO: Westview Press.

Clark, J.F. (2002) 'The neo-colonial context of the democratic experiment of Congo-Brazzaville', African Affairs 101(403): 171-192.

Clark, J.F. and Gardinier, D.E. (eds.) (1997) Political Reform in Francophone Africa, Boulder, CO: Westview Press.

Dahl, R.A. (1971) Polyarchy: Participation and Opposition, New Haven: Yale University Press.

Dahl, R.A. (1989) Democracy and its Critics, New Haven and London: Yale University Press.

Dahl, R.A. (1998) On Democracy, New Haven and London: Yale University Press.

Davis, J.U. and Kossomi, A.R. (2001) 'Niger gets back on track', Journal of Democracy 12(3): 80-87.

Decalo, S. (1997) 'Benin: First of the New Democracies', in J.F. Clark and D.E. Gardinier (eds.) Political Reform in Francophone Africa, Boulder, CO: Westview Press.

Decalo, S. (1998) The Stable Minority: Civilian Rule in Africa, Gainesville and London: Florida Academic Press.

Diamond, L. (1999) Developing Democracy: Toward Consolidation, Baltimore and London: The Johns Hopkins University Press.

Diamond, L., Linz, J.J. and Lipset, S.M. (eds.) (1990) Politics in Developing Countries: Comparing Experiences with Democracy, Boulder, CO: Lynne Rienner Publishers.

Dobzhansky, T., Ayala, F.J., Stebbins, G.L. and Valentine, J.W. (1977) Evolution, San Francisco, CA: W.H. Freeman \& Company.

The Economist (2001), London: The Economist Newspapers Ltd.

The Economist (2002), London: The Economist Newspapers Ltd.

The Economist (2003), London: The Economist Newspapers Ltd.

FAO (1997) Report on the 1990 World Census of Agriculture. International comparison and primary results by country (1986-1995), Rome: Food and Agriculture Organization of the United Nations.

Fomunyoh, C. (2001) 'Democratization in fits and starts', Journal of Democracy 12(3): 37-50.

Galvan, D. (2001) 'Political turnover and social change in Senegal', Journal of Democracy 12(3): 51-62.

Gardinier, D.E. (1997) 'Gabon: Limited Reform and Regime Survival', in J.F. Clark and D.E. Gardinier (eds.) Political Reform in Francophone Africa, Boulder, CO: Westview Press.

Gervais, M. (1997) 'Niger: Regime Change, Economic Crisis, and Perpertuation of Privilege', in J.F. Clark and D.E. Gardinier (eds.) Political Reform in Francophone Africa, Boulder, CO: Westview Press.

Gilliomee, H., Myburgh, J. and Schlemmer, L. (2001) 'Dominant party rule, opposition parties and minorities in South Africa', Democratization 8(1): 161-182. 
Glickman, H. (1995a) 'Issues in the Analysis of Ethnic Conflict and Democratization Processes in Africa Today', in H. Glickman (ed.) Ethnic Conflict and Democratization in Africa, Atlanta, GA: The African Studies Association Press.

Glickman, H. (1995b) 'The Management of Ethnic Politics and Democratization in Tanzania', in H. Glickman (ed.) Ethnic Conflict and Democratization in Africa, Atlanta, GA: The African Studies Association Press.

Glickman, H. (ed.) (1995c) Ethnic Conflict and Democratization in Africa, Atlanta, GA: The African Studies Association Press.

Gwartney, J. and Lawson, R. (with Samida, D.) (2000) Economic Freedom of the World. 2000 Annual Report, Canada: The Fraser Institute.

Hadenius, A. (1992) Democracy and Development, Cambridge: Cambridge University Press.

Heilbrunn, J.R. (1997) 'Togo: The National Conference and Stalled Reform', in J.F. Clark and D.E. Gardinier (eds.) Political Reform in Francophone Africa, Boulder, CO: Westview Press.

Helsingin Sanomat (2003) Helsinki.

Idehuru, O.M. (1999) The Politics of Economic Restructuring and Democracy in Africa, Westport: Greenwood Press.

Internationales Afrikaforum (2003), Bonn: Weltforum Verlag.

Inter-Parliamentary Union (IPU) (2003) Chronicle of Parliamentary Elections, 1 January - 31 December 2002, Geneva: Inter-Parliamentary Union.

Karatnycky, A., Motyl, A. and Schnetzer, A. (2001) Nations in Transit 2001: Civil Society, Democracy and Markets in East Central Europe and Newly Independent States, United States: Freedom House.

Lanne, B. (1997) 'Chad: Change, Increased Insecurity, and Blockage of Further Reforms', in J.F. Clark and D.E. Gardinier (eds.) Political Reform in Francophone Africa, Boulder, CO: Westview Press.

Lodge, T. (2001) 'The Namibian elections of 1999', Democratization 8(2): 191-230.

Longman, T. (1997) 'Rwanda: Democratization and Disorder: Political Transformation and Social Deterioration', in J.F. Clark and D.E. Gardinier (eds.) Political Reform in Francophone Africa, Boulder, BO: Westview Press.

Makumbe, J. (2002) 'Zimbabwe's hijacked election', Journal of Democracy 13(4): 87-101.

Manning, C. (2001) 'Competition and accommodation in post-conflict democracy: the case of Mosambique', Democratization 8(2): 140-168.

Maphai, T.V. (1995) 'Liberal Democracy and Ethnic Politics: A Prolegomenon', in H. Glickman (ed.) Ethnic Conflict and Democratization in Africa, Atlanta, GA: The African Studies Association Press.

Marty, M. (2002) 'Mauritania: political parties, neo-patrimonialism and democracy', Democratization 9(3): 92-108.

May, R. and Massey, S. (2002) 'The Chadian party system: rhetoric and reality', Democratization 9(3): 72-91.

Mayr, E. (1982) The Growth of Biological Thought: Diversity, Evolution, and Inheritance, Cambridge, MA: Harvard University Press.

Mayr, E. (1988) Toward a New Philosophy of Biology, Cambridge, MA: Harvard University Press.

Mbaku, J.M., Agbese, P.O. and Kimenyi, M.S. (eds.) (2001) Ethnicity and Governance in the Third World, Aldershot: Ashgate.

Meyns, P. (2002) 'Cape Verde: an African exception', Journal of Democracy 13(3): 153-165.

Midlarsky, M.I. (ed.) (1997) Inequality, Democracy, and Economic Development, Cambridge: Cambridge University Press. 
Muigai, G. (1995) 'Ethnicity and the Renewal of Competitive Politics in Kenya', in H. Glickman (ed.) Ethnic Conflict and Democratization in Africa, Atlanta, GA: The African Studies Association Press.

Mundt, R.J. (1997) ‘Cote d'Ivoire: Continuity and Change in a Semi-Democracy', in J.F. Clark and D.E. Gardinier (eds.) Political Reform in Francophone Africa, Boulder, CO: Westview Press.

N'Diaye, B. (2001) 'Mauritania's stalled democratization', Journal of Democracy 12(3): 88-95.

Nmoma, V. (1995) 'Ethnic Conflict, Constitutional Engineering and Democracy in Nigeria', in H. Glickman (ed.) Ethnic Conflict and Democratization in Africa, Atlanta, GA: The African Studies Association Press.

O'Toole, T. (1997) 'The Central African Republic: Political Reform and Social Malaise', in J.F. Clark and D.E. Gardinier (eds.) Political Reform in Francophone Africa, Boulder, CO: Westview Press.

Przeworski, A., Alvarez, M.E., Cheibub, J.A. and Limongi, F. (2000) Democracy and Development: Political Institutions and Well-Being in the World, 1950-1990, Cambridge: Cambridge University Press.

Rueschemeyer, D., Stephens, E.H. and Stephens, J.D. (1992) Capitalist Development and Democracy, Cambridge: Polity Press.

Saine, A. (2002) 'Post-coup politics in the Gambia', Journal of Democracy 13(4): 167-172.

Saine, A. (2003) 'The presidential election in the Gambia, October 2001', Electoral Studies 22: $375-381$.

Sithole, M. (1995) 'Ethnicity and Democratization in Zimbabwe: From Confrontation to Accommodation', in H. Glickman (ed.) Ethnic Conflict and Democratization in Africa, Atlanta, GA: The African Studies Association Press.

Smith, D.A. (2002) 'Consolidating democracy? The structural underpinnings of Ghana's 2000 elections', Journal of Modern African Studies 40(4): 621-650.

Smith, Z.K. (2001) 'Mali's decade of democracy', Journal of Democracy 12(3): 73-79.

Takougang, J. (1997) ‘Cameroon: Biya and Incremental Reform', in J.F. Clark and D.E. Gardinier (eds.) Political Reform in Francophone Africa, Boulder, CO: Westview Press.

Toungara, J.M. (2001) 'Ethnicity and political crisis in Cote d'Ivoire', Journal of Democracy 12(3): 63-72.

Turner, T. (1997) 'Zaire: Flying High Above the Toads: Mobuto and Stalemated Democracy', in J.F. Clark and D.E. Gardinier (eds.) Political Reform in Francophone Africa, Boulder, CO: Westview Press.

Ukiwo, U. (2003) 'Politics, ethno-religious conflicts and democratic consolidation in Nigeria', Journal of Modern African Studies 41(1): 115-138.

UNDP (the United Nations Development Programme) (2000) Human Development Report 2000, New York: Oxford University Press.

UNDP (2001) Human Development Report 2001. Making New Technologies Work for Human Development, New York: Oxford University Press.

UNESCO (1999) Statistical Yearbook 1999, Paris: Unesco Publishing \& Bernan Press.

Vanhanen, T. (1997) Prospects of Democracy: A Study of 172 Countries, London and New York: Routledge.

Vanhanen, T. (1999a) Ethnic Conflicts Explained by Ethnic Nepotism, Research in Biopolitics, Vol. 7. Stamford, CT: JAI Press.

Vanhanen, T. (1999b) 'Domestic ethnic conflict and ethnic nepotism: a comparative analysis', Journal of Peace Research 36(1): 55-73.

Vanhanen, T. (2000) 'A new dataset for measuring democracy', Journal of Peace Research 37(2): 251-265.

Vanhanen, T. (2003) Democratization: A Comparative Analysis of 170 Countries, London and New York: Routledge. 
Vener, J.I. (2000) 'Prompting democratic transitions from abroad: international donors and multi-partyism in Tanzania', Democratization 7(4): 133-162.

Vengroff, R. and Creevey, L. (1997) 'Senegal: The Evolution of a Quasi Democracy', in J.F. Clark and D.E. Gardinier (eds.) Political Reform in Francophone Africa, Boulder, CO: Westview Press.

Walle, N. van de (2002) 'Africa's range of regimes', Journal of Democracy 13(2): 66-80.

Weinstein, J.M. (2002) 'Mozambique: a fading UN success story', Journal of Democracy 13(1): $141-156$.

The World Bank (2000) World Development Report 1999/2000. Entering the 21st Century, New York: Oxford University Press.

The World Bank (2001) World Development Report 2000/2001. Attacking Poverty, New York: Oxford University Press.

\section{Notes}

1 A first draft has been presented at the 19th IPSA World Congress, in Durban, South Africa.

2 I thank the NOS-S project 'Democracy and Peace: A Nordic Model?' for travel grants.

3 Empirical data on the results of elections and other political events needed to calculate the values of the three measures of democracy in the years 1999-2002 for the 45 sub-Saharan African countries are presented and documented in a separate appendix, which is available from the author. 